\begin{tabular}{|c|c|c|c|}
\hline & \multicolumn{2}{|c|}{ R\&S - RESEARCH STUDIES ANATOLIA JOURNAL } & \\
\hline Anatolia Journal & www.dergipark.org.tr/rs & Vol: 2, Issue: 5, pp; 172-184 & $=$ \\
\hline
\end{tabular}

\title{
SOCIAL AND HUMAN SCIENTIFIC
}

Durmaz, Y. Düzgün, M. ve Sürme, M. (2019). “Genç Tüketicilerin Yiyecek ve İçecek Tercihlerini Etkileyen Faktörler Ve Gaziantep Merkezinde Bir Araştırma”, Vol:2, Issue:5; pp: 172-184

\begin{aligned} & \hline \hline $\begin{array}{l}\text { Anahtar Kelimeler: Tüketici Davranışı, Fast Food, Yiyecek } \\ \text { ve İçecek, Fast Food İşletmesi, Yiyecek ve İçecek İşletmesi. }\end{array} \begin{array}{l}\text { Keywords: Consumer Behaviour, Fast Food, Food } \\ \text { and Beverage, Fast Food Business, Food and } \\ \text { Beverage Business. }\end{array} \\ &$\hline \hline Makale Türü Araştırma Makalesi \\ & \hline \hline\end{aligned}

\section{GENÇ TÜKETİCILLERIN YIYYECEK VE İÇECEK TERCİHLERINII ETKİLEYEN FAKTÖRLER VE GAZİANTEP MERKEZINDE BİR ARAŞTIRMA}

\author{
Factors Affecting Food and Beverage Preferences of Young Consumers and A Research in \\ Gaziantep Center \\ Yakup DURMAZ ${ }^{1}$ \\ Mehmet DÜZGÜN² \\ Metin SÜRME ${ }^{3}$ \\ Geliş Tarihi / Arrived Date \\ Kabul Tarihi / Accepted Date \\ 29.04.2019 \\ Yayınlanma Tarihi / Published Date \\ 17.04.2019
}

ÖZ

ABSTRACT

İnsanlar tüketim davranıșlarını yönlendiren bir takım değer ve There are some values and criteria that shapes the kriterler söz konusudur. Bu değer ve kriterler genel anlamda consumption behaviors of people. These values and olduğu gibi yiyecek ve içeceklerin tercihinde de geçerli criteria are valid both in the general sense and in the olmaktadır. Bu araştırmada genç tüketicilerin yiyecek ve choice of food and drinks. In this research, the criteria that içecekleri tercih ederken referans aldıkları kriterler young consumers consider while buying food and drinks belirlenmiş, söz konusu kriterlerin yoğun yaşam temposu has been detected and the relationship between these içinde yiyecek ve içecek tüketimi açısından önemli bir yer criteria and the consumer behavior towards fast food tutan fast food işletmelerine yönelik tüketici davranışı businesses, which have an important place in terms of food arasındaki ilişki ortaya konulmaya çalışılmıştır. Bu amaçla and drinks, has been tried to be revealed. The oluşturulan anket 394 genç tüketici üzerinde uygulanmıştır. questionnaire for this research was conducted on 394 $\mathrm{Bu}$ araștırma sonucunda genç tüketicilerin yiyecek ve young consumers. The findings of this research suggest içecekleri tercih ederken faydacı değerleri benimsedikleri fast that young consumers adopt pragmatic values while food işletmelerine güvendikleri ancak söz konusu işletmelere choosing food and drinks, they trust the fast food yönelik bağlılıklarının düşük olduğu tespit edilmiştir. Bununla businesses but their dependence on them is low. It has also beraber araştırmada faydacılık değeri artarken yiyecek içecek been detected that when the pragmatic value increases the memnuniyetinin de arttığı belirlenmiştir. Araştırma satisfaction of food and drinks also increases. Another bulgularına göre dikkat çeken bir diğer sonuç ise UNESCO important finding is that young consumers living in Kültür mirası listesinin gastronomi kategorisinde yer alan Gaziantep, which is in the category of gastronomy in Gaziantep'te yaşayan genç tüketicilerin yiyecek ve içecek UNESCO cultural heritage list, adopt socio-cultural values tercihinde sosyo-kültürel değerleri daha az benimsemiş less in their food and drink choices. olmalarıdır.

\section{GíRiş}

Pazarlama sistemi içinde yer alan elemanlar arasında tüketiciler en önemli ve en karmaşık elemanlar olarak karşımıza çıkmaktadır. Satın alma süreci açısından değerlendirildiğinde tüketicilerin bu son kararını etkileyen bir çok içsel ve dışsal faktörün olduğu bilinmektedir. Yapılan araştırmalarda tüketici davranışlarının oldukça karmaşık ve kapsamlı bir yapıya sahip olduğu ortaya konmuştur. Temel olarak tüketici davranışları ihtiyacın ortaya çıkması, bilgi arama, alternatiflerin değerlendirilmesi, satın alma

\footnotetext{
1 iD Hasan Kalyoncu Üniversitesi, İktisadi İdari ve Sosyal Bilimler Fakültesi, İşletme Bölümü, Dr. Öğr. Üyesi, yakup.durmaz@hku.edu.tr

2 iD Hasan Kalyoncu Üniversitesi, İşletme Bölümü, Doktora Öğrencisi, duzgun0627@gmail.com 
ve satın alma sonrası davranışlar olmak üzere beş aşamadan oluşmaktadır. Söz konusu aşamaların her birinde tüketici davranışlarının bilinmesi yiyecek içecek işletmelerindeki pazarlama yöneticilerinin tüketicilerin beklentilerini karşılayacak şekilde üretim yapılmasını, müşteri sayısının artırılmasını, satışlardaki artışı ve marka sadakatinin oluşturulmasını sağlayabilmeleri açısından büyük önem arz etmektedir.

Tüketici davranışları pazarlama bileşenleri ile beraber kültürel psikolojik ve sosyo-demografik bir çok faktörden etkilenmektedir. Bu bağlamda tüketici davranışlarını sadece ürünün ekonomik bedelinin ödenerek satın alınması șeklinde değerlendirmek oldukça yetersiz kalacaktır. Temelde tüketici davranışlarını sağlıklı bir şekilde değerlendirebilmek için insanların davranış süreçlerini de ele almak gerekmektedir. $\mathrm{Bu}$ açıdan insanların davranışları çevreleri ile olan etkileşimin bir sonucu olarak karşımıza çıkmaktadır. Konuya genç tüketiciler açısından bakıldığında özellikle satınalma karınının oluşmasında bireyinin sosyal çevresinin etkili olduğunu söylemek mümkündür. Teknolojik gelişmelerin hız kazanmış olması tüketicilere bilgiye rahat ulaşma noktasında önemli avantajlar kazandırmıștır. $\mathrm{Bu}$ durumun ise pazarlamacıların ișlerini daha da zorlaștırdığını söylemek mümkündür. Çünkü müșteriler farklı alternatiflere daha hızlı bir șekilde ulașabilmektedir. Yiyecek içecek işletmelerinde tüketici daranışlarınının incelenmesinde ise bazı belirleyici bazı kriterlere bakmak gerekmektedir. Bu bağlamda yapılan bu araştırmada katılımcılara öncelikle yiyecek ve içecek seçiminde tercih kriterleri sorulmuş alınan cevaplar doğrultusunda ise fast food yiyecek içecek işletmelerindeki tüketim davranışları ele alınmıştır.

Bu çalışma UNESCO kültür mirası listesinin mutfak kategorisinde yer alan ve dünyaca bilinen bir şehir mutfağına sahip olmasından dolayı Gaziantep’te gerçekleștirilmiştir. Bu sebepten dolayı yapılan bu araştırma sonuçları bakımından oldukça önemlidir.

\section{LITERATÜR TARAMASI}

Literatürde tüketici davranışı araştırmalarını konu alan araştırmaların daha çok giysi tercihi üzerinde (Ağaç ve Harmankaya 2009; Aktuğlu ve Temel 2006) reklamların ve renklerin tüketim tercihlerine etkisi (Çakır vd. 2010; Yağcı ve İlarslan 2011; Çağlayan vd., 2016) tüketici memnuniyeti (Duman 2003; Durmaz 2006; Yaman 2013) sosyal medya ve internetin tüketici davranışı üzerinde etkisi (Yıldız 2014; Keskin ve Baş 2015; Turan 2011) konularına odakandığı görülmektedir. Hizmet sektöründe yiyecek içecek ișletmelerine yönelik daha önce yapılmıș araștırmalar da ise personel kalitesi, müșteri memnuniyeti, tüketim tavsiyesi yada işletmelere yönelik algı ve tutumlarının ele alındığı tespit edilmiștir (Ünal vd., 2014:24). Literatürde fast food ișletmelerine yönelik yapılan araștırma konuları ve elde edilen sonuçlar ise şu şekilde özetlenebilir:

Sürücüoğlu ve Çakıroğlu (2000), 886 üniversite öğrencisi üzerinde hızlı hazır yemek alışkanlıklarına yönelik yapmış oldukları araştırmalarında üniversite öğrencilerinin hızlı hazır yemek işletmelerini tercih etmeyip geleneksel yiyecek çecek işletmelerini tercih ettiklerini tespit etmişlerdir.

Lombert (2000), fast-food işletmelerdeki bekleme sürelerine ilişkin tüketici algılarını belirlemeye çalıştığı araştırmada, tüketicilerin bekleme sürelerini önemsediklerini sonucuna ulaşmışlardır.

Goyal ve Signh (2007), Hindistan'da fast food işletmelerine yönelik tüketici algısını konu alkıkları araştırmalarında genç tüketicilerin eğlence ve değişim için fast food satış noktalarını ziyaret etme tutkusuna sahip olduklarını, bununla birlikte gençlerin ev yapımı yiyeceklerin fast food satışlarında servis edilen yemeklerden daha iyi olduğunu düşündüklerini tespit etmişlerdir.

Öncü vd., (2007), McDonald's ta yemek yemeyi tercih eden 736 müşteri üzerinde hızlı yiyecek isletmelerini tercih eden müsterilerin tercihinde etkili olan faktörleri saptamakve bu faktörler ile tüketicilerin demografik özellikleri arasında farkı tespit etmeyi konu aldıkları araştırmalarında, tüketicilerin gelir düzeyleri, medeni durumları, cinsiyet durumları ve eğitimleri ile ilgili anlamlı farklılıklar olduğunu tespit etmişlerdir.

Hacıefendioğlu ve Koç (2009), fast food sektöründe hizmet kalitesi algılamalarının müşteri bağlılığına etkisini konu aldıkları araştırmalarında, müșteri bağlılığını etkileyen hizmet kalitesi boyutlarının geçmiş deneyimler, değer, güvenilirlik ve yiyecek kalitesi olduğunu tespit etmişlerdir. Qin ve Prybutok (2009), araştırmalarında fiyat, besin değeri, kuruluşun temizliği, hizmet hızının müşteri memnuniyetini ve sadakatini etkilediğini ortaya koymuşlardır.

\section{$R \& S$ \\ Research Studies Anatolia Journal \\ Volume: 2, Issue:5, April 2019}


Kobayashi (2011), Japon lise öğrencilerinin televizyon izleme oranları ile fast food tüketimini konu aldığı araştırmasında düşük oranda TV izleyen öğrencilerin haftalık fast food tüketiminde, orta veya yüksek oranda TV izleyeyen öğrencilere göre önemli ölçüde daha az para harcadığını; erkek öğrencilerin ise haftalık fast-food yemek tüketimine kız öğrencilerden daha fazla para harcadıklarını tespit etmiştir.

Kayışoğlu ve İçöz (2012), 900 kişi üzerinde eğitim düzeyinin fast- food tüketim alışkanlığına etkisini konu aldıkları araştırmalarında, eğitim düzeyi ile fast food yiyecek tüketiminin ters orantılı olduğunu saptamışlardır.

Caraher vd., (2012), Londra'daki ortaokulların çevresindeki fast-food kuruluşlarının lokasyonu ile öğrencilerin fast-food yiyecek seçimleri üzerindeki etkisini konu aldıkları araştırmalarında araștırmaya katılan öğrencilerin öğle yemeklerini söz konusu işletmelerde yemek için para biriktirdiklerini ve öğle yemeklerini okullarının olduğu lokasyondaki fast food işletmeledinden temin ettiklerini tespit etmişlerdir.

Hamşığlu (2013), fast food ürünleri satın alan tüketicilerin yaşam tarzlarını belirlemeye yönelik 600 katılımcı üzerinde gerçekleștirdiği araştırmasında araștırmaya katılanların ifade ettikleri yaşam tarzları ve fast food yiyecek tüketim alışkanlıkları arasında anlamlı ilişki olduğunu tespit etmiştir.

Olcay ve Döş (2014), Adıyaman ve Gaziantep' te ikamet eden 407 katılımcı üzerinde fast-food ișletmelerini tercih nedenlerini konu aldıkları araștırmalarında araștırmaya katılanlardan bu işletmeleri tercihlerinde yaş ile eğitim düzeyi değişkenlerinin etkili olduğu ve bu etkinin büyüklügünün ise küçük olduğunu tespit etmişlerdir.

Küçükergin ve Dedeoğlu (2014) Fast food restoranlarda fiziksel çevre, fiyat algısı ve tekrar satın alma eğilimi arasındaki ilişkiyi konu aldıkları araştırmalarında fiyat algısının tekrar satın alma niyeti üzerindeki etkisinin olumlu yönde ve anlamlı olduğunu tespit etmişlerdir.

Gram vd., (2015), üniversite öğrencileri ile ebeveynleri arasında kuşaklararası ilişkilerin sürdürülmesinde yiyecek içecek tüketim uygulamalarının anlamını ele aldıkları araştırmalarında ev dışında yemek tüketim alışkanlıklarının öğrencilerin ailelerinden uzaklaşması üzerinde etkili olduğunu tespit etmişlerdir.

Can (2016), fast food sektöründe marka deneyimi ve algılanan reklam harcamalarının, marka değerini oluşturan marka bağlılığı üzerindeki etkisini konu aldığı araştırmasında marka deneyiminin marka farkındalığı ve hedonik duyguları etkilediği sonucunu tespit etmiştir.

Kellershohn vd., (2018), İngiltere' de 4-6 yaş arası 20 çocuk üzerinde sağlıklı yiyecekler ile fast food ürünlerin tüketimini karşılaştırdıkları araştırmalarında çocukların bütün meyveleri daha lezzetli, daha sağlıklı ve daha ebeveyn onaylı olduğunu değerlendirdiklerini tespit etmişlerdir.

\subsection{Tüketici Davranıșı}

Tüketici davranışı, kısaca ürün ve hizmetleri tercih etme, alma, elden çıkarma faaliyetleri olarak tanımlanabilmektedir. Pazarlama açısından üretilen ürünlerin tüketiciler tarafından satınalınıp kullanılmasına yönelik karar ve davranış süreçleri tüketici davranışı olarak değerlendirilmektedir. Farklı bir ifade ile tüketici davranıșı temel olarak satınalmaya yönelik karar verme süreçlerini ve bir ürüne sahip olup ondan faydalanmaya yönelik olan süreçleri içerir (Çivitçi, Çakmak ve Işık,2006:203). Tüketici davranışının temel özellikleri ise şu șekilde ifade edilebilir (Odabaşı ve Barıș,2002):

Tükeci davranışı Karmaşık bir yapıya sahiptir

Tüketici davranışı bireyin çevresi ile olan ilişkisinden ayrı değildir.

Tüketici davranışı güdülenmiş bir davranıştır.

Tiketici davranışı dinamik bir süreçtir.

Tüketici davranışı zamanlama açısından farklılık arz edebilir.

Tüketici davranışı içerisinde belli bir amacı barındıran güdülenmiş bir davranıştır.

Tüketicilerin ihtiyaçları sınırsızdır. Tüketicilerin sınırsız olan söz konusu ihtiyaçları ise üreticiler tarafından sağlanan ürün veya hizmetler tarafından karşılanmaktadır. Üreticiler bir taraftan tüketicilerin ihtiyaçlarını karşılarken beraberinde kar elde etmektdirler. Pazarlama ise işletmelerin 
kar amacına ulaşmalarında en etkili işletme fonksiyonu olarak karşımıza çıkmaktadır (Akat vd., 2006:15). Bununla birlikte çağdaş pazarlama anlayışı açısından tüketicilerin eğilim ve isteklerinin belirlenmesi de pazarlamanın temel çalışma konuları arasındadır (Akat, 2004).

Pazarlamacıların temel görevi tüketicilerin ürünlere yönlendirilmesidir. Tüketiciler ise sunulanlar içinden kendilerine yani ihtiyaçlarına en uygun olanları seçmektedirler. Pazarlamanın esas amacı ise insanların ihtiyaçlarını karşılamaktır. Bu amacı karş̧layabilmek için ilk olarak tüketicilerin mal ve hizmetleri nereden, nasıl, neden aldığını araştırmak gerekmektedir. Tüketicilerin kritik ihtiyaçların tespit etmeden ihtiyaçları olan doğru mal ve hizmetleri üretmek mümkün değildir. Buradan hareketle pazarlamacıların hedef kitleye yönelik yapacakları analizlerin oldukça önemli olduğunu söylemek mümkündür. Değișen koșullar özellikle birbirine özellik olarak yakın ya da ikame ürün ve hizmetlerin farklı piyasalarda var olması tüketicileri satınalma davranışına yönelik olarak ücret ödemenin bir adım ötesinde bir tercihte bulunmaya zorlamaktadır. Çünkü bu şartlar altında tüketiciler tercih ettikleri ürünlerin diğer ürünlere göre sağladığı artı değerlere göre hareket etmektedirler (Eriş ve Kutlu, 2007: 2-3).

\subsection{Yiyecek İçecek İşletmeleri}

Turizm sektörü nitelik açısından birbirinden oldukça farklı işletmeleri kapsamakla beraber özellikle yiyecek içecek işletmeleri bireylerin ihtiyaçlarını sürekli bir şekilde karşılamaya devam etmektedirler. Günümüzde yiyecek içecek işletmeleri de tıpkı turizm sektörünün genelinde olduğu gibi çok farklı nitelikler içermekte ve sayıları gün geçtikçe artmaktadır. Bununla birlikte yiyecek içecek işletmelerinde üretilen yiyecek içeceklerle birlikte müșteri memnuniyetinin üst düzeyde sağlanması büyük önem arz etmekedir. Bu sebeplerden dolayı özellikle yiyecek içecek işletmeleri üzerine yapılan bilimsel çalışmalar artış göstermekte ve elde edilen veriler ışığında sektöre bilgi akışı sağlanmaktadır (Ünal vd., 2014:24).

İşletmecilik açısından oldukça eski bir tarihe sahip olan yiyecek içecek işletmelerinin başlangıcının kentleşme ile başladığı değerlendirilmektedir (Olcay ve Döș, 2014:161). Yiyecek içecek işletmeleri müşterilere yeme içme imkanı sağlayan ișletmeler olarak tanımlanmaktadır (Maviș, 2005:7). Yiyecek içecek işletmeleri rekabetin artması ile beraber her geçen gün hızlı bir şekilde büyümeye devam etmektedir. Sözkonusu büyümenin temel nedenleri; teknolojinin yiyecek içecek üretimine etkisi, sosyalleşme, kadınların iş yaşımında artan oranda aktif olarak yer alması, gelir düzeyindeki artış, yüksek iş temposu olarak sıralanabilir (Bekar ve Dönmez, 2016:2). Yiyecek içecek işletmeleri açısından uzun vadeli stratejilerin belirlenmiș olması gelecekte karșlanması muhtemel bir çok soruna karşı önceden tedbir alınmasına katkı sağlayacaktır (Güler,2007:103).

\subsection{Fast Food İşletmeleri}

Başlangıçta Güney Kaliforniya'da 1940'larda ortaya çılkmıș olan fast food ișletmeleri, sadece Amerikalıların yeme-içme alışkanlıklarını değiștirmekle kalmamış aynı zamanda dünyanın birçok ülkesindeki söz konusu değișimin gerçekleșmesinde etkili olmuștur (Kobayashi, 2011:242). Her ne kadar fast-food sektörünün büyümesinin obezite oranlarında görülen artış ile ilişkili olduğu değerlendirilsede fast food işletmelerinin sayısı her geçen gün artmaktadır (Critser, 2003). Fast food yiyecekler hızlı hazırlanması, makul fiyatlı oluşu sebeplerinden dolayı ev yapımı yemeklere alternatif olarak sunulmaktadır. Yoğun bir yaşam tarzı için uygun ve ekonomik gibi görünse de, fast food yiyecekler tipik olarak yağ, doymuş yağ, şeker ve tuz bakımından yüksek değerlere sahiptir. Bu duruma rağmen söz konusu yiyeceklerin tüketimindeki artış devam etmektedir. (Goyal ve Signh, 2007:183).

Türkiye'de fast food endüstrisi 1980'lerden itibaren oldukça hızlı bir büyüme sergilemiştir. Son yirmi yılda Türkiye'de tüketicilerin yaşam biçimleri, eğitim, gelir ve tüketim kalıplarındaki büyük değişiklikler tüketicileri fast food işletmelerinde yemek yemeye teşvik etmiştir. Yeni kurulan alışveriş merkezlerindeki artan fast-food zincirleri ve restoranlar, bu yeni ortaya çıkan talebin kanitı olarak gösterilebilir (Akbay vd., 2007:904-905). Artan bu taleple beraber fast food işletmelerinin sayısı da hızlı bir artış göstermiştir. Bu artışın sebepleri arasında kadınların iş yaşamında daha fazla yer alması, dışarda yemek yeme alışkanlığının kazanılması, nufus artışı, bireylerin gelir düzeyindeki artış,boş zaman artışı, kentleşme ve demografik özelliklerin farklılaşması gösterilebilir (Olcay ve Döş, 2014; Öncü vd., 2007). Bu durum rekabetin de artmasıyla beraber müșterilen beklentilerini de yükseltmektedir (Uygur ve Küçükergin, 2013:383).

\section{$\mathrm{R} \& S$}

Research Studies Anatolia Journal

Volume: 2, Issue:5, April 2019 


\section{ARAŞTIRMANIN YÖNTEMI}

Araștırmanın bu kısmında araștırmanın amacı ve önemi, anakütle ve örneklem, araștırmada kullanılan anket formunun içeriği ve ölçüm güvenirliği ile veri toplama aracının çözümlenmesine yönelik sayısal bilgilere yer verilmiştir.

\subsection{Araştırmanın Amacı ve Önemi}

İnsanlar tüketim davranışlarını yönlendiren bir takım değer ve kriterler söz konusudur. Bu değer ve kriterler genel anlamda olduğu gibi yiyecek ve içeceklerin tercihinde de geçerli olmaktadır. Bu araştırmada genç tüketicilerin yiyecek ve içecekleri tercih ederken referans aldıkları kriterler belirlenmiș ve söz konusu kriterlerin yoğun yașam temposu içinde yiyecek ve içecek tüketimi açısından önemli bir yer tutan fast food işletmelerine yönelik tüketici davranışı arasındaki ilişki ortaya konulmaya çalışılmıştır. Dolayısıyla yapılan bu araştırmanın temel amacını gençlerin fast food işletmelerine yönelik tüketici davranışlarını yiyecek ve içecek tercih kriterleri değişkeni açısından incelemek oluşturmaktadır.

Araştırma Gaziantep'te gerçekleştirilmiştir. Araştırmanın söz konusu şehirde yapılmış olması sonuçlar ititbarı ile büyük önem arz etmektedir. Gaziantep UNESCO (Birleşmiş Milletler Eğitim, Bilim ve Kültür Örgütü)'nün 2004 yılında kurmuş olduğu yaratcı șehirler ağının gastronomi kategorisine 2015 yılında kabul edilmiştir. Bu anlamda dünyaca ünlü bir mutfağa sahip olan söz konusu şehirdeki tüketicilerin yiyecek içecek tüketim ya da tercih kriterlerinin oldukça önemli olduğunu söylemek mümkündür. Bununla birlikte bu araştırmada genç tüketicilerin fast food işletmelerine yönelik bakış açıları ortaya konulmuş buradan hareketle tüketici davranışı ayrı faktörler halinde incelenmiștir.

\subsection{Anakütle ve Örneklem}

Yapılan bu araștırmada anakütleyi Gaziantep’te fast food yiyecek içecek işletmelerini ziyaret eden genç tüketiciler oluşturmaktadır. Araştırmada tüm tüketicilere ulaşmanın mümkün olmamasından dolayı örnekleme yapılması gerekli görülmüştür. Örnekleme yöntemi olarak ise kolayda örnekleme yöntemi tercih edilmiştir. $\mathrm{Bu}$ araştırmada örneklem büyüklüğü belirlenirken $\mathrm{a}=0.05$ için örnekleme hatası $(d)= \pm 0,05$ olarak belirlenmştir $(p=0,5 ; q=0,5)$. Buna göre bu araştırmada belirlenen evreni temsil etme yeteneğine sahip örneklem büyüklüğü 384'tür (Altunışık vd. 2007:127). Araştırma Gaziantep il merkezinde gerçekleştirilmiştir. Araştırmanın Gaziantep’te gerçekleștirilmiş olmasının temel sebebi UNESCO'nun yaratıcı şehirler ağı listesinin gastronomi kategorisinde yer alan sadece sekiz şehire ek olarak dokuzuncu şehir olarak eklenmiş olmasıdır. Buradan hareketle söz konusu şehirde yaşayan insanların yiyecek ve içeceklere yönelik tercih ya da tüketim bilgisinin daha üst seviyede olduğu söylenilebilir. Bu bağlamda Gaziantep'te fast food işletmelerini yiyecek veya içecek tüketimi amacıyla ziyaret eden 400 genç tüketiciye ulaşılmış ancak hatalı ya da eksik doldurulan altı anket analizlere dahil edilmemiş 394 anket formu ile analizler gerçekleștirilmiştir.

\subsection{Anakütle Formunun İçeriği ve Ölçeğin Güvenirliliği}

Genç tüketicilerin yiyecek ve içecek tercih kriterlerinin fast food işletmelerinde tüketici davranışı üzerindeki etkisini tespit etmeye yönelik yapılmış olan bu araştırmada veriler anket tekniği ile elde edilmiştir. Anket formu üç bölümden oluşmaktadır. Birinci bölümde katılımcılara yönelik demografik bilgileri içeren sekiz soru, ikinci bölümde katılımcıların yiyecek içecekleri tercih kriterlerini içeren on bir ifade, üçüncü ve son bölümde ise yiyecek içecek işletmelerine yönelik tüketici davranışını içeren yirmi iki ifade yer almaktadır. Anket formunun ikinci bölümünde Lusk ve Briggeman (2009) tarafından geliştirilen yiyecek içecek değer ölçeğinde yer alan on bir ifade yer almaktadır. Üçüncü bölümde ise genç tüketicilerin yiyecek ve içecek tercih kriterlerinin fast food işletmelerinde tüketici davranışı üzerindeki etkisini ortaya koymak için Yusta vd. (2018)' in çalışmalarında kullanmış oldukları anket formundan faydalanılmıştır. Anket uygulaması 2018 yılının Eylül ve Aralık ayları arasında araştırmacılar tarafından geçekleştirilmiştir. Yapılan bu araştırma kapsamında ölçümün güvenirliği için Cronbach's Alpha katsayısı hesaplanmıştır. Buna göre anket formunda yer alan 33 ifade için Cronbach's Alpha 0,909 yiyecek ve içecek tercih kriterlerini içeren 11 ifade için Cronbach's Alpha 0,860 gençlerin fast food yiyecek içecek işletmelerinde tüketici davranışını ortaya koyan 22 ifade için ise Cronbach"s Alpha 0,943 olarak hesaplanmıştır. Alpha katsayısı 0,00-0,39 ise ölçüm güvenilir değil, 0,40-0,59 ise ölçümün güvenirliği düşük, 0,60-0,79 ise ölçüm oldukça güvenilir, 0,801,00 ise ölçüm yüksek güvenirliğe sahip olarak değerlendirilir (Akbulut, 2010:80). İfadelerin tamamı tamamı göz önünde bulundurulduğunda ölçümünün yüksek derecede güvenilir olduğunu söylemek mümkündür.

\section{$\mathrm{R} \& S$}

Research Studies Anatolia Journal

Volume: 2, Issue:5, April 2019 


\subsection{Veri Toplama Aracının Çözümlenmesi}

Yapılan bu araştırmadan elde edilmiş olan verilerin analizi SPSS 21 paket programında gerçekleştirilmiştir. Anket formunda yer alan maddelerinin yüksek derecede güvenilir olduğu tespit edildikten sonra veri setinin faktör analizi için gereken şartları karşılayıp karşılamadığı incelenmiştir. $\mathrm{Bu}$ aşamada öncelikle örneklem büyüklüğüne bakılması gerekmektedir. Comrey ve Lee (1992), 300 katılımcının örneklem büyüklüğü şartının sağlanması için yeterli olduğunu ifade etmiştir. Diğer taraftan Kline (1994), güvenilir faktörlerin belirlenebilmesi için 200 kișilik örneklem sayısının genel anlamda yeterli olduğunu ancak daha iyi sonuçların elde edilebilmesi için daha büyük örneklem sayısı üzerinde çalışılması gerektiğini belirtmiştir. Buradan hareketle örneklem büyüklüğünün faktör analizi için yeterli olduğunu söylemek mümkündür. Sonraki aşamada değişkenler arasında bir ilişkinin olup olmadığını tespit etmek amacıyla Bartlett Küresellik testi uygulanmış anketin ikinci bölümünü olușturan 11 ifade ve üçüncü bölümünü olușturan 22 ifade için $p=0,000$ olduğu görülmüştür. Bununla birlikte değişkenler arasındaki ilişkinin faktör analizine uygunluğunu tespit etmek amacıyla gerçekleştirilen Kaiser-Meyer-Olkin (KMO) testinde KMO değeri ikinci bölüm için 0,841 üçüncü bölüm için ise 0,934 olarak hesaplanmıştır.

Araştırmada anket formunun ikinci bölümü için Skewness katsayısı -0,134 $\pm 0,123$ Kurtosis katsayısı $0,450 \pm 0,245$ olarak hesaplanmıştır. Buna göre veriler parametrik testler için gereken varsayımları karşılamaktadır. Ancak bununla yetinilmeyip verilerin histogram dağılımı da Şekil 1'de gösterilmiştir

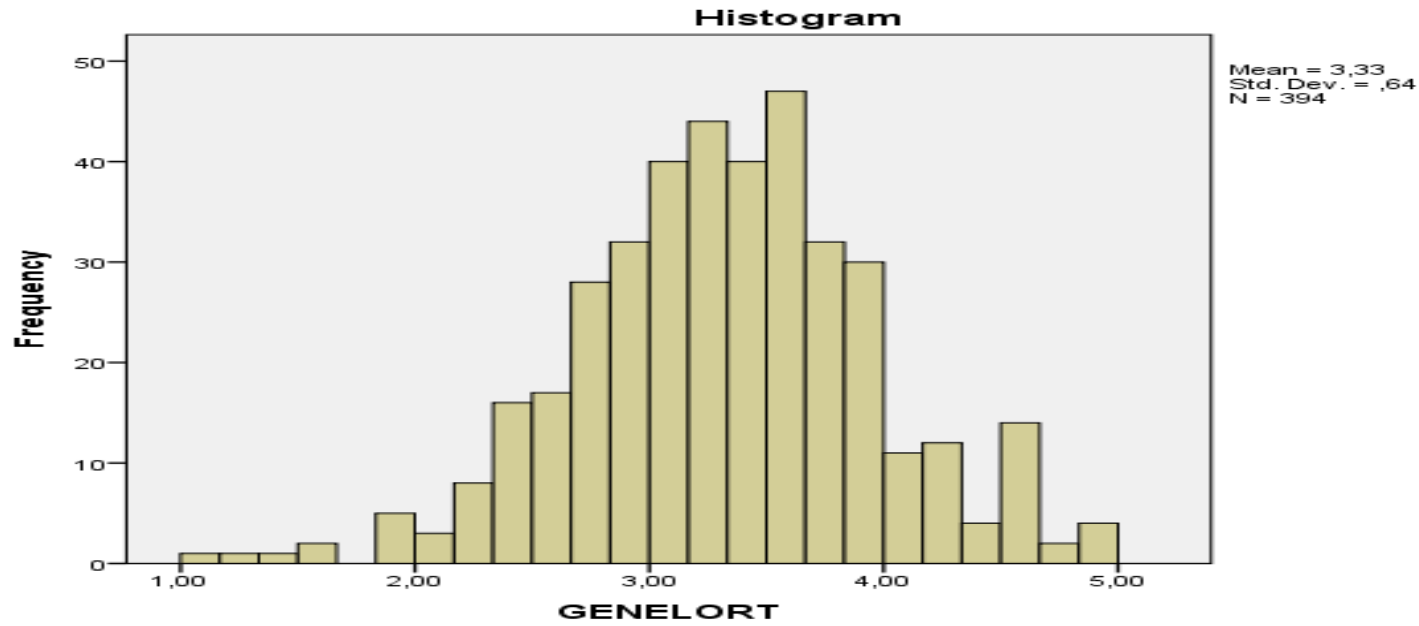

Şekil 1: Verilerin Histogram Dağılımı

\section{BULGULAR}

Araştırmaya katılan 394 katılımcının 209'u (\%53) erkek 185' ise (\%47) ise kadındır. Katılımcıların $353^{\prime}$ ü $(\% 89,6)$ 18-25 yaş aralığında 35'i $(\% 8,9)$ 25-35 yaş aralığında ve 6'sı $(\% 1,5)$ 35-45 yaş aralığında bulunmaktadır. Araștırmaya katılan genç tüketicilerin 25 ' $\mathrm{i}(6,3)$ fast food ișletmlerini yalnız, 23 'ü $(\% 5,8)$ aile üyeleri ile 299 'u $(\% 75,9)$ arkadaşları ile 4'ü $(\% 1)$ meslektaşları ile 25'i ise $(\% 6,3)$ partneri ile ziyaret ettiklerini ifade etmişlerdir. Bununla birlikte katılmcılardan 112'si $(\% 28,4)$ fast food işletmelerini ayda birden daha az 93'ü $(\% 26,6)$ ayda bir defa , 91'i $(\% 23,1)$ haftada bir defa, 80'i $(\% 20,3)$ haftada birkaç defa 18 i ise $(\% 4,6)$ her gün ziyaret ettiklerini belirtmişlerdir. Araștırmaya katılan tüketicilerden yiyecek ve içecekleri tercih ederken gözönüne aldıkları kriterleri puanlamaları istenmiş ve sonuçlar tabloda gösterilmiştir. Buna göre araştırmaya katılanların tüketecekleri yiyecek ve içeceklerde aradıkları kriterler bakımından lezzet kriterinin daha ön planda olduğu tespit edilirken geleneklerin ise diğer kiriterlere göre arka planda kaldığı belirlenmiş, sonuçlar Tablo 1'de gösterilmiştir. 
Tablo 1. Yiyecek ve İçecek Tercih Kriterlerinin Artimetik Ortamala ve Standart Sapma Değerleri

\begin{tabular}{lcc}
\hline & Ortalama & Standart Sapma \\
\hline Görünüm & 4,2500 & 1,04053 \\
Lezzet & 4,5612 &, 96310 \\
Fiyat & 3,9156 & 1,30200 \\
Kolayerişim & 4,1832 & 1,13336 \\
Köken & 3,2718 & 1,47515 \\
Gelenekler & 3,2595 & 1,47025 \\
Çevresel Etki & 3,4703 & 1,31966 \\
Güvenilirlik & 4,1883 & 1,26417 \\
Dürüstlük & 4,1933 & 1,26863 \\
Besin Değeri & 3,6701 & 1,45423 \\
\hline
\end{tabular}

Tablo 1'de gösterildiği gibi araştırmaya katılan genç tüketiciler yiyecek ve içecek tercihlerindeki en önemli kriterli sırasıyla lezzet $(\bar{x}=4,56 \pm 0,9)$, görünüm $(\bar{x}=4,25 \pm 1,04)$, dürüstlük $(\bar{x}=4,19 \pm 1,26)$ güvenilirlik $(\overline{\mathrm{x}}=4,18 \pm 1,26)$ ve kolay erişim $(\overline{\mathrm{x}}=4,18 \pm 1,13)$ olarak ifade etmişlerdir. Diğer taraftan fiyat $(\overline{\mathrm{x}}=3,91 \pm 1,30)$, gelenekler $(\overline{\mathrm{x}}=3,25 \pm 1,47)$, çevresel etki $(\overline{\mathrm{x}}=3,47 \pm 1,31)$ ve besin değeri $(\overline{\mathrm{x}}$ $=3,67 \pm 1,45$ ) gibi kriterler daha önemsiz kriterler olarak ifade edilmiştir.

\subsection{Faktör Analizi}

Araştırmada farklı kavramaların ölçümünün yapılması amacı ile kullanılan ifadeler üzerinde açımlayıcı faktör analizi gerçekleştirilmiștir. Bu doğrultuda temel bileşenler analiz yöntemi kullanılmış faktör sayılarının tespit edilmesinde ise özdeğerin birden büyük olması kriteri kullanılmıştır. Bununla birlikte faktörler belirlenirken binişik maddelerin olduğu görülmüş ve tüketici davranışları ölçeğinde (S4,S6, S22) yiyecek ve içecek tercih kriterlerine ölçeğinde ise (S4) faktör analizine dâhil edilmemiştir. Gerçekleştirilen analiz neticesinde katılımcıların yiyecek içecek tercih kriterlerini ortaya koyan üç faktörlü bir yapı tespit edilirken gençlerin fast food işletmelerinde tüketici davranışını ortaya koyan dört faktörlü bir yapıya ulaşılmıştır. Buna göre anketin ikinci ve üçüncü bölmümleri için 300 serbestlik derecesinde KMO değerleri sırası ile 0,841 ve 0,934 olarak tespit edilmiştir. Bununla birlikte anketin ikinci ve üçüncü bölümü için Bartlett testleri anlamlı çıkmış ikinci bölüm için (Ki Kare $=1510,840$, sd=45, p=0,00) üçüncü bölüm için ise (Ki Kare $=4389,802$, sd= 190, p=0,00) olarak hesaplanmıştır. Faktörlere yüklenmiş olan soru gruplarının güvenilirliklerini tespit etmek için her bir soru grubu için Cronbach's Alfa katsayısı hesaplanmış sonuçlar Tablo 2 ve Tablo 4'te gösterilmiştir. Güvenilirlik değerlerinin yeterli olduğu belirlenen soru gruplarının sonraki analizler için kullanılabilmesi amacıyla ortalamaları alınmış ve yeni değişkenler oluşturulmuştur. Buna göre yiyecek ve içecek tercih kriterleri etik değerler, faydacı değerler ve sosyo kültürel ve çevresel değerler olarak adlandırlırken tüketici davranışını konu alan sorular ise işletme memnuniyeti, güven, sadakat ve yiyecek içecek memnuniyeti olarak adlandırılmıştır.

Tablo 2. Yiyecek ve İçecek Tercih Kriterlerine İlişkin Faktörler ve Cronbach Alfa Değerleri

\begin{tabular}{|c|c|c|c|}
\hline \multicolumn{4}{|c|}{ Faktör analizi } \\
\hline \multirow[b]{2}{*}{ Iffadeler } & \multicolumn{3}{|c|}{$\begin{array}{l}\text { Faktörler } \\
\end{array}$} \\
\hline & Etik Değerler & Faydacı Değerler & Sosyo Kültürel ve Çevresel Değerler \\
\hline Görünüm & & 652 & \\
\hline Lezzet & & ,719 & \\
\hline Fiyat & & ,781 & \\
\hline Kolay erişim & & ,618 & \\
\hline Köken & & & ,789 \\
\hline Gelenekler & & & ,830 \\
\hline Çevresel etki & & & ,696 \\
\hline Güvenilirlik & ,805 & & \\
\hline Dürüstlük & ,797 & & \\
\hline Besin değeri & ,794 & & \\
\hline $\begin{array}{l}\text { Cronbach's Alpha } \\
\text { Değerleri }\end{array}$ & 0,82 & 0,72 & 0,72 \\
\hline \multicolumn{4}{|c|}{$\begin{array}{l}\text { Extraction Method: Principal Component Analysis. Rotation Method: Varimax with Kaiser } \\
\text { Normalization. }\end{array}$} \\
\hline a. Rotation converg & 5 iterations. & & \\
\hline
\end{tabular}


Tablo 2'de gerçekleştirilmiş olan faktör analizi sonuçları gösterilmiştir. Buna göre genç tüketicilerin yiyecek ve içecek tercih kriterini belirleyen üç faktörlü bir yapıya ulaşılmış faktör yük değerleri ve Cronbac's Alpha değerleri gösterilmiștir. İfadelerin faktör yük değerlerinin 0,618 ile 0,830 arasında olduğu tespit edilmiştir. Yapılan analiz sonucunda ulaşılmış olan faktörler "Etik Değerler, Faydacı Değerler ve Sosyo-kültürel Değerler” olarak isimlendirilmiş ve faktörlere ilişkin ortalama ve standart sapma değerleri hesaplanarak Tablo 3'te gösterilmiştir.

Tablo 3. Yiyecek İçecek Tercih Keriterlerine İlişkin Faktör İstatistikleri

\begin{tabular}{|l|c|c|}
\hline & Ortalama & Standart Sapma \\
\hline Etik Değerler & 4,0172 & 1,14924 \\
\hline Faydacı Değerler & 4,2275 &, 82973 \\
\hline Sosyo Kültürel Değerler & 3,3339 & 1,14516 \\
\hline
\end{tabular}

Tablo 3'te Etik Değerler, Faydacı Değerler ve Sosyo-kültürel Değerler" faktörlerine ilişkin ortalama ve standart sapma değerleri gösterilmiştir. Buna göre genç tüketicilerin yiyecek ve içecekleri tercih ederken en fazla faydacı değerleri $(\bar{x}=4,22 \pm, 82)$, benimsedikleri tespit edilmiştir.

Tablo 4. Tüketici Davranışlarına İlişkin Faktörler ve Cronbach's Alfa Değerleri

\begin{tabular}{|c|c|c|c|c|}
\hline \multicolumn{5}{|c|}{ Faktör Analizi } \\
\hline \multirow[b]{2}{*}{ İfadeler } & \multicolumn{4}{|c|}{ Faktörler } \\
\hline & $\begin{array}{c}\text { İşletme } \\
\text { Memnuniyeti }\end{array}$ & Güven & Sadakat & $\begin{array}{c}\text { Yiyecek- } \\
\text { İçecek } \\
\text { Memnuniyeti }\end{array}$ \\
\hline $\begin{array}{l}\text { (1) Fast food işletmelerinde üretilen yiyecekler } \\
\text { beklentilerimi karşllar. }\end{array}$ & & & & ,795 \\
\hline $\begin{array}{l}\text { (2) Fast food işletmelerinde üretilen yiyecekler tatmin } \\
\text { edicidir. }\end{array}$ & & & & ,787 \\
\hline $\begin{array}{l}\text { S3) Fast food işletmelerinde hazırlanan yiyecekler } \\
\text { memnun edicidir. }\end{array}$ & & & & 791 \\
\hline $\begin{array}{l}\text { (5) Fast food işletmelerinden genel anlamda } \\
\text { memnunum. }\end{array}$ & & & & ,589 \\
\hline $\begin{array}{l}\text { (7) Fast food işletmeleri vaatlerini (sözlerini) yerine } \\
\text { getirir }\end{array}$ & 605 & & & \\
\hline (8) Fast food işletmelerinin sağladı̆̆ı bilgiler doğrudur. & ,761 & & & \\
\hline (9) Fast food işletmeleri dürüst işletmelerdir. & 823 & & & \\
\hline (10) Fast food ișletmeleri güvenilir ișletmelerdir & ,799 & & & \\
\hline (11) Fast food ișletmeleri samimi işletmelerdir. & ,666 & & & \\
\hline (12) Fast food işletmeleri profesyonel işletmelerdir. & & ,720 & & \\
\hline (13) Fast food ișletmelerinin teknik imkanları yeterlidir & & ,785 & & \\
\hline $\begin{array}{l}\text { (14) Fast food işletmelerinde çalışanların nitelikleri } \\
\text { yeterlidir. }\end{array}$ & & ,724 & & \\
\hline $\begin{array}{l}\text { (15) Fast food işletmelerininde müşteriler tatmin } \\
\text { olmaktadır }\end{array}$ & & ,511 & & \\
\hline (16) Fast food işletmelerinde işler düzgün yürür. & & ,603 & & \\
\hline (17) Fast food işletmelerinden kolay bilgi sağlanır. & &, 540 & & \\
\hline $\begin{array}{l}\text { (18) Ev dışında yemeklerimi fast food işletmelerinde } \\
\text { tüketirim. }\end{array}$ & & & ,775 & \\
\hline (19) Fast food işletmelerini tanıdıklarıma tavsiye ederim. & & & ,737 & \\
\hline $\begin{array}{l}\text { (20) Fast food işletmeleri ev dışında yemek için en iyi } \\
\text { seçenektir }\end{array}$ & & & 807 & \\
\hline (21) Fast food ișletmelerini düzenli ziyaret ederim. & & & ,766 & \\
\hline Cronbach's Alpha Değerleri & 0,87 & 0,83 & 0,85 & 0,893 \\
\hline
\end{tabular}


Tablo 4'te araștırmaya katılan genç tüketiclerin fast food işletmelerine yönelik tüketici davranışına ilişkin gerçekleştirilmiş olan faktör analizi sonuçları gösterilmiştir. Buna göre genç tüketicilerin tüketici davranıșını gösteren dört faktörlü bir yapıya ulașılmıș faktör yük değerleri ve Cronbac's Alpha değerleri gösterilmiștir. İfadelerin faktör yük değerlerinin ise 0,511 ile 0,823 arasında olduğu tespit edilmiștir. Yapılan analiz sonucunda ulaşılmıș olan faktörler 'İşletme Memnuniyeti, Güven, Sadakat ve Yiyecek İçecek Memnuniyeti' olarak isimlendirilmiş ve faktörlere ilişkin ortalama ve standart sapma değerleri hesaplanarak Tablo 5'te gösterilmiştir

Tablo 5. Tüketici Davranışlarına İlișkin Faktör İstatistikleri

\begin{tabular}{|l|c|c|}
\hline & Ortalama & Standart Sapma \\
\hline Güven & 3,3210 &, 89181 \\
\hline Yiyecek Memnuniyeti & 3,2995 & 1,07244 \\
\hline Sadakat & 2,7995 & 1,14269 \\
\hline İşletmeme Memnuniyeti & 2,8768 &, 97753 \\
\hline
\end{tabular}

Tablo 5'te 'İșletme Memnuniyeti, Güven, Sadakat ve Yiyecek İçecek Memnuniyeti' faktörlerine ilișkin ortalama ve standart sapma değerleri gösterilmiştir. Buna göre araştırmaya katılan genç tüketicilerin fast food işletmelerine güven düzeylerinin yüksek olduğu $(\bar{x}=3,32 \pm, 89)$ diğer taraftan söz konusu işletmelere yönelik olarak sadakatlerinin ise memnuniyet faktörlerinin gerisinde kaldığı tespit edilmiştir $(\bar{x}=2,79 \pm 1,14)$.

\subsection{Regresyon Analizi}

Araştırmada genç tüketicilerin yiyecek ve içecek ve içecek tercih kriterlerinin tüketici davranışı üzerindeki etkisini tespit etmek amaciyla "Güven" , "Yiyecek İçecek Memnuniyeti" "Sadakat" ve "İşletme Memnuniyeti" nin bağımlı "Etik Değerler, Faydacı Değerler ve Sosyo-kültürel Değerler" in ise bağımsız değişken olarak kabul edildiği regresyon analizleri gerçekleştirilmiştir. Söz konusu analizlerin gerçekleştirilebilmesi için öncelikle verilerin regresyon analizine yönelik ön koşulları sağlayıp sağlamadığına bakılmıștır. Bu amaçla öncelikle tolerans ve VIF değerleri hesaplanmıștır. Bu değerler araștırmanın bağımsız değişkenleri arasında yüksek korelasyon olup olmadığını belirlemektedir. Bununla birlikte hata terimleri arasındaki oto korelasyonun tespit edilebilmesi için verilerin Durbin-Watson değerleri hesaplanmıș ve ilgili tablolarda gösterilmiștir. Durbin-Watson değerinin 2'ye yakın olması hata terimleri arasındaki oto korelasyonun düşük olduğunu göstermektedir. Diğer taraftan hata terimlerinin normal bir dağılım göstermiş olması ve bağımsız değișkenlere ilișkin hata varyansının sabit olduğu görülmüș bu bilgilerden hareketle verilerin regresyon analizine tabi tutulabileceğine kanaat getirilmiştir. Gerçekleștirilmiş olan analiz sonuçları aşağıda gösterilmiştir

Tablo 6. Güven Bağımsız Değişkeni İle Yiyecek ve İçecek Tercih Kriterlerine Yönelik Regresyon Testi Sonuçları

\begin{tabular}{|c|c|c|c|c|c|}
\hline Bağımlı değișken: Güven & & & Durbin- & n: 1,79 & \\
\hline Bağımsız değişkenler & B & Std. Error & Beta & $\mathbf{t}$ & Sig. \\
\hline 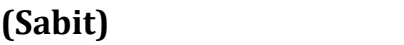 & 2,773 & ,239 & & 11,615 & ,000 \\
\hline Etikdeğerler & ,069 & 049 & 089 & 1,404 & 161 \\
\hline Faydacı değerler & 099 & ,065 & 092 & 1,520 & 129 \\
\hline Sosyo-Kültürel Değerler &,- 044 & ,044 &,- 057 & $-1,010$ & ,313 \\
\hline
\end{tabular}

Tablo 6'ya göre bă̆ımsız değişkenler olan "Etik Değerler, Faydacı Değerler ve Sosyo-kültürel Değerler" ele alındığında bağımlı değişken "Güven" ile aralarında istatistiksel olarak anlamlı bir ilişki tespit edilememiştir.

Tablo 7. Yiyecek İçecek Memnuniyeti Bağımsız Değişkeni İle Yiyecek ve İçecek Tercih Kriterlerinin Karşılaştırılmasına Yönelik Regresyon Testi Sonuçları

\begin{tabular}{lccccc}
\hline $\begin{array}{l}\text { Bağımlı Değişken: Yiyecek- } \\
\text { İçecek Memnuniyeti }\end{array}$ & \multicolumn{2}{c}{$\mathbf{R}^{\mathbf{2}} \mathbf{0} \mathbf{0 , 3 2}$} & \multicolumn{2}{c}{ Durbin-Watson: 1,66 } & \\
\hline $\begin{array}{l}\text { Bağımsız değişkenler } \\
\text { (Sabit) }\end{array}$ & $\mathbf{B}$ & Std. Error & Beta & $\mathbf{t}$ & Sig. \\
Etik değerler & 2,273 &, 284 & & 7,993 &, 000 \\
Faydacı değerler &, 052 &, 058 &, 056 &, 891 &, 374 \\
Sosyo-kültüreldeğerler &, $\mathbf{2 2 8}$ & $\mathbf{, 0 7 8}$ &, $\mathbf{1 7 6}$ & $\mathbf{2 , 9 2 5}$ &, $\mathbf{0 0 4}$ \\
&,- 043 &, 052 &,- 046 &,- 829 &, 408
\end{tabular}


Tablo 7’ye göre bağımsız değișkenler göz önüne alındığında etik değerler ve sosyo kültürel değerler değişkenleri istatistiksel anlamsız çıkmıștır. Faydacı değerler değişkeni ise istatistiksel olarak anlamlıdır. Dolayısıyla faydacılık değeri artarken yiyecek içecek memnuniyeti de artmaktır.

Tablo 8. Sadakat Bağımsız Değișkini İle Yiyecek ve İçecek Tercih Kriterlerinin Karşılaştırılmasına Yönelik Regresyon Testi Sonuçları

\begin{tabular}{lccccc}
\hline Bağımlı Değişken: Sadakat & \multicolumn{2}{c}{$\mathbf{R}^{\mathbf{2}} \mathbf{: 0 , 0 2}$} & \multicolumn{3}{c}{ Durbin-Watson: 1,84 } \\
\hline Bağımsız Değişkenler & $\mathbf{B}$ & Std. Error & Beta & t & Sig. \\
(Sabit) & 2,729 &, 308 & & 8,872 &, 000 \\
Etikdeğerler &, 117 &, 063 &, 117 & 1,850 &, 065 \\
Faydacl &,- 049 &, 084 &,- 036 &,- 587 &, 557 \\
Sosyo-Kültürel Değerler &,- 057 &, 057 &,- 057 & $-1,003$ &, 317 \\
\hline
\end{tabular}

Tablo 8'e göre bağımsız değișkenler olan "Etik Değerler, Faydacı Değerler ve Sosyo-kültürel Değerler" ele alındığında bağımlı değişken "Sadakat" ile aralarında istatistiksel olarak anlamlı bir ilişki tespit edilememiştir.

Tablo 9. İşletme Memnuniyeti Bağımsız Değișkini İle Yiyecek ve İçecek Tercih Kriterlerinin Karşılaştırılmasına Yönelik Regresyon Testi Sonuçları

\begin{tabular}{lrrrrr}
\hline Bağımlı Değişken: İşletme Memnuniyeti & \multicolumn{2}{c}{$\mathrm{R}^{2}: 0,04$} & \multicolumn{2}{c}{ Durbin-Watson: 1,79 } \\
\hline Bağımsız Değişkenler & B & Std. Error & Beta & t & Sig. \\
(Sabit) & 2,681 &, 264 & & 10,161 &, 000 \\
Etik Değerler &, 029 &, 054 &, 034 &, 539 &, 590 \\
Faydacı &,- 015 &, 072 &,- 013 &,- 204 &, 838 \\
Sosyo-Kültürel Değerler &, 042 &, 049 &, 050 &, 872 &, 384 \\
\hline
\end{tabular}

Tablo 9'a göre bağımsız değișkenler olan "Etik Değerler, Faydacı Değerler ve Sosyo-kültürel Değerler" ele alındığında bağımlı değișken "İșletme Memnuniyeti” ile aralarında istatistiksel olarak anlamlı bir ilişki tespit edilememiştir

\section{SONUÇLAR VE ÇIKARIMLAR}

Genç tüketicilerin yiyecek ve içecek tercih kriterlerinin fast food işletmelerine yönelik tüketici davrnışı arasındaki ilişkiyi tespit etmek amacıyla gerçekleștirilen bu araștırmada elde edilen sonuçlara göre katılımcıların 209'u (\%53) erkek 185' ise (\%47) ise kadındır. Katılımcıların 353'ü $(\% 89,6)$ 18-25 yaș aralığında, 35'i $(\% 8,9)$ 25-35 yaş aralığında ve 6'sı $(\% 1,5)$ 35-45 yaș aralığında bulunmaktadır. Araştırmaya katılan tüketiciler en önemli yiyecek ve içecek tercih krtielerini lezzet ve görünüm olarak ifade erderken en düşük ortalamaları gelenekler, çevresel etki ve besin değeri olarak belirtmişlerdir (Bkz. Tablo 1). Bu sonuç özellikle genç tüketicilerin yemek tüketim alışkanlıklarında gelenekler çevresel etki ve besin değeri kriterlerini diğer kriterlere göre daha az önemsediğini ortaya koymaktadır. Elde edilen bu sonuç Goyal ve Signh (2007) ve Sürücüoğlu ve Çakıroğlu (2000) tarafından yapılan çalıșmalarda elde edilen sonuçlar ile çelişmektedir. Sürücüoğlu ve Çakıroğlu (2000) araştırmada üniversite öğrencilerinin hızlı hazır yemek işletmelerini tercih etmeyip geleneksel yiyecek çecek işletmelerini tercih ettiklerini tespit etmişlerdir. Goyal ve Signh (2007) ise yapmış oldukları araştırmalarında gençlerin ev yapımı yiyeceklerin fast food işletmelerinde servis edilen yemeklerden daha iyi olduğunu düşündüklerini tespit etmişlerdir. Araştırma kapsamında elde edilen yiyecek ve içecek tercih kriterleri üzerinde gerçekleștirilen faktör analizi istatistikleri de söz konusu araştırmalarda elde edilen sonuçlar ile de örtüşmemektedir. Araştırma kapsamında elde edilen faktör istatistiklerine göre sıralama faydacı değerler etik değerler ve sosyo kültürel değerler şeklinde tespit edilmiştir (Bkz Tablo:4). Sosyokültürel değerlerin son sırada yer alması özellikle Gaziantep gibi UNESCO'nun kültür mirası listesinde yer alan Gaziantep Mutfağı'nın sonraki kuşaklara aktarılmasını olumsuz etkileyebileceği için oldukça düşündürücüdür. Çünkü bu sonuç genç tüketicilerin bir anlamda geleneksel yemek tüketim alışkanlıklarını beklentinin aksine daha az önemsediklerini, faydacı değerleri ise daha fazla benimsediklerini ortaya koymaktadır. Diğer tarftan araştırmaya katılan genç tüketicilerin fast food işletmelerine yönelik tüketici davranışı incelendiğinde katılımcılar fast food işletmelerini güvenilir olarak nitelemekte ancak söz konusu işletmelere olan sadakat duygularının daha düşük değerler aldığı görülmektedir (Bkz. Tablo 5). 
Araștırmaya katılan tüketicilerin yiyecek ve içecekleri tercih kriterleri ile fast işletmelerine yönelik tüketici davranıșı arasındaki ilişkiyi görebilmek için regresyon analizi gerçekleștirilmiştir. Elde edilen sonuçlarda "Etik Değerler, Faydacı Değerler ve Sosyo-kültürel Değerler" ile "Güven, Sadakat ve İşletme Menuniyeti " arasında anlamlı bir ilişki tespit edilememiştir. Öte yandan 'Faydacı Değerler' ile 'Yiyecek İçecek Memnuniyeti' arasında anlamlı ve pozitif yönlü bir ilișkinin olduğu tespit edilmiştir. Buna göre yiyecek ve içeceklerin satın alınmasında görünüm, lezzet, fiyat ve kolay erişim değerini benimsemiş olan genç tüketiciler fast food işletmelerinde üretilen yiyeceklerden memnun olduklarını dolayısıyla söz konusu işletmelerin beklentilerini karşılaşmış oldukları söylenilebilir. Bu bulgular ise Hacıefendioğlu ve Koç (2009) tarafından fast food sektöründe hizmet kalitesi algılamalarının müşteri bağlılığına etkisini konu aldıkları araştırmalarında elde edilen sonuçları destekler niteliktedir. Söz konusu araștırmada müşteri bağlılığını etkileyen hizmet kalitesi boyutlarının geçmiş deneyimler, değer, güvenilirlik ve yiyecek kalitesi olduğunu tespit etmişlerdir. Bununla beraber "Etik Değerler, Faydacl Değerler ve Sosyo-kültürel Değerler" ile "İşletme Memnuniyeti" arasında istatistiksel olarak anlamlı bir ilişki tespit edilememiştir. Bu sonuç ise Bowen ve Chen (2001) ile Kumar ve Şah (2004) tarafından yapılan araştırmalarda elde edilen sonuçlar ile örtüşmemektedir. Her iki araștırmada da sadakat ve müşteri memnuniyeti arasında anlamlı bir ilişki olduğu belirlenmiştir.

$\mathrm{Bu}$ araştırmanın temel amacı göz önünde bulundurulduğunda araştırmaya katılan genç tüketicilerin yiyecek ve içecek tercih kriterleri bakımından faydacı değerleri daha çok benimsedikleri dolayısıyla yiyecek tercihinde en önemli kriterlerin lezzet ve görünüm olduğu görülmektedir. Bununla birlikte tüketici davranışı bakımından genç tüketicilerin fast food ișletmelerine güvendiği, bu işletmelerde üretilen yiyeceklere yönelik memnun oldukları tespit edilmiştir. Bu durumun aksine genç tüketicilerin fast food işletmelerine yönelik bağlllıklarının ise düşük olduğu görülmektedir. Fast food işletmeleri açısından müşteri bağlılığı krtik bir öneme sahiptir. Bu bağlamda pazarlama faaliyetleri açısından fast food işletmelerinin genç tüketicilerin müşteri bağlılığını artırabilmeleri için özellikle genç tüketiciler açısından yeni stratejiler geliştirmelerinin gerekli olduğu değerlendirilmektedir.

Yapılan bu araştırmadan elde edilen sonuçlardan hareketle yiyecek içeceklerin tercih edilmesinde yiyeceklerin sadece lezzet ve görünüm açısından değil besin değeri ve köken bakımından da değerlendirilmesine yönelik tüketicileri bilinçlendirebilecek akademik çalışmaların gerçekleştirilmesi gerektiği söylenilebilir.

\section{KAYNAKÇA}

Ağaç, S. ve Harmankaya, H. (2009). İlköğretim Birinci Kademe Öğrencilerin Giysi Tercihleri ve Giysi Satın Alma Davranışlarına Etki Eden Faktörler. Selçuk Üniversitesi Sosyal Bilimler Enstitüsü Dergisi, 22, 1-13.

Akbay, C., Tiryaki, G. Y. ve Gül, A. (2007). Consumer Characteristics Influencing Fast Food Consumption in Turkey. Food Contol, 18(8), 904-913.

Akat, Ö. (2004). Uluslararası Pazarlama Karması ve Yönetimi. 5. Baskı, Ekin Kitabevi, Bursa.

Akat, Ömer; C..,Taşkın ve A., Özdemir (2006). Uluslararası Alışveriş Merkezi Tüketicilerinin Satın Alma Davranışı Bursa İlinde Bir Uygulama. Anadolu Üniversitesi Sosyal Bilimler Dergisi, 6(2), 13-30.

Akbulut, Y. (2010). Sosyal bilimlerde SPSS uygulamaları. İstanbul: İDEAL Kültür Yayıncılık.

Altunışık, R., Recai C., Bayraktaroğlu S. ve Yıldırım E. (2007). Sosyal Bilimlerde Araştırma Yöntemleri Spss Uygulamalı 5.Baskı, Sakarya Yayıncılık, Sakarya.

Aktuğlu K. I. ve Temel A., (2006). Tüketiciler markaları nasıl tercih ediyor? Kamu sektörü çalışanlarının giysi markalarını tercihini etkileyen faktörlere yönelik bir araştırma. Konya Selçuk Üniversitesi Sosyal Bilimler Enstitüsü Dergisi, 15, 43-59.

Bekar, A. ve Dönmez, F. G. (2016). Tüketicilerin dışarıda yemek yeme nedenlerine ilişkin bir değerlendirme. Social Sciences, 11(1), 1-15.

Bowen, J.T. and Chen, S.-L. (2001). The Relationship Between Customer Loyalty And Customermsatisfaction. International Journal of Service Industry Management, 15(4), 213-217. 
Can, P. (2016). Marka Deneyimi, Hedonik Duygular ve Algılanan Reklam Harcamalarının Marka Değeri Boyutlarına Etkisi Üzerine Fast Food Sektöründe Bir Araștırma. Uluslararası Yönetim İktisat ve İşletme Dergisi, 12(30),121-143.

Caraher, S. M. Lloyd, T. Madelin, (2014). The "School Foodshed": schools and fast-food outlets in a London borough. British Food Journal, 116(3), 472-493.

Critser, G. (2003). Fat Land: How Americans Became the Fattest People in the World. Houghton Mifflin, New York, NY

Comrey, A. L., and Lee, H. B. (1992). A First Course in Factor Analysis . Hillsdale, NJ, Lawrence Eribaum Associates. Inc., Publishers.

Çağlıyan, V. I., Zeynep. E.. ve Hassan, S. A. (2016). Üniversite Öğrencilerinin Satın Alma Davranışlarında Sosyal Medya Reklamlarının Etkisi: Selçuk Üniversitesi'nde Bir Araştırma. Selçuk Üniversitesi Sosyal Ve Teknik Araştırmalar Dergisi,11, 43-56.

Çakır, M., Çakır, F. ve Usta, G. (2010). Üniversite Öğrencilerinin Tüketim Tercihlerini Etkileyen Faktörlerin Belirlenmesi. Organizasyon Ve Yönetim Bilimleri Dergisi, 2(2), 87-94.

Çivitci, Ş. C.., F. Zeynep, Işık, E. (2006). Yerli ve Yabancı Markalı Giysi Seçiminde Tüketicilerin Karar Verme Tarzları. Mesleki Ĕgitim Fakültesi Dergisi, 1(1), 202-212.

Duman, T. (2003). Richard L. Oliver'ın Tüketici Memnuniyeti (Customer Satisfaction) ve Tüketici Değer Algısı (Consumer Value) Kavramları Hakkındaki Görüșleri. Dokuz Eylül Üniversitesi Sosyal Bilimler Enstitüsü dergisi 5(2), 45-56.

Durmaz,Y. (2006). Modern Pazarlamada Tüketici Memnuniyeti ve Evrensel Tüketici Hakları. Journal of Yaşar University, 3(1), 255-266.

Eriș, N. ve Kutlu, Ș. (2007). Marka bağlılı̆̆ı yaratmada müșteri ilișkileri yönetimi. Ankara Üniversitesi Sosyal Bilimler Enstitüsü İșletme Ana Bilim Dall, Ankara, Mayıs, 26.

Gram, M. Hogg M, Blichfeldt S.B., MacLaran, P. (2015). Intergenerational relationships and food consumption: the stories of young adults leaving home. Young Consumers, 16 (1),71-84.

Hamşıŏlu, A.B. (2013). Fastfood ürünleri satın alan tüketicilerin yaşam tarzlarını belirlemeye yönelik bir uygulama. Uluslararası Íktisadi ve İdari Íncelemeler Dergisi, 11, 18-32.

Güler, S. (2007). Yiyecek ve İçecek İşletmeleri İçin Rekabet Avantajı Yaratacak Stratejik Seçenekler. Anatolia: Turizm Araştırmaları Dergisi, 18(1), 101-104.

Goyal, A. and N.P. Singh, (2007). Consumer perception about fast food in India: an exploratory study. British Food Journal, 109 (2), 182-195.

Hacıefendioğlu, Ș. ve Koç, Ü. (2009). Hizmet Kalitesi Algılamalarının Müşteri Bağlılığına Etkisi ve FastFood Sektöründe Bir Araștırma. Kocaeli Üniversitesi Sosyal Bilimler Enstitüsü Dergisi, 2(18), 146-167.

Kayıșoğlu, S. ve İçöz, A. (2012). Eğitim Düzeyinin Fast-Food Tüketim Alıșkanlığına Etkisi. Tekirdağ Ziraat Fakültesi Dergisi, 9(2), 16-19.

Kellershohn, J., Walley,K. Vriesekoop,F. (2018). Young children's perceptions of branded healthy fast food. British Food Journal, 120(11), 2569-2581.

Kline, P. (1994). An Easy Guide To Factor Analysis:. New York: Routledge.

Keskin, S. ve Baş, M. (2015). Sosyal Medyanın Tüketici Davranışları Üzerine Etkisinin Belirlenmesi. Gazi Üniversitesi IIBF Dergisi, 17(3), 51-69.

Kobayashi F. (2011) Japanese High School Students' Television Viewing And Fast Food Consumption. Nutrition \& Food Science,.41(4), 242-248.

Kumar, V. and Shah, D. (2004). Building and sustaining profitable customer loyalty for the 21st century. Journal of Retailing, 80 (4), 317-329. 
Küçükergin, K. G. ve Dedeoğlu, B. B. (2014). Fast Food Restoranlarda Fiziksel Çevre, Fiyat Algısı ve Tekrar Satın Alma Eğilimi Arasındaki İlişki. Uluslararası Alanya İşletme Fakültesi Dergisi, 6(1), 101-107.

Lee, W. and Lombert, C. U. (2000). Impact Of Waiting Time On Evaluation Of Service Quality And Customer Satisfaction In Foodservice Operations. Food Service Research International, 12 (4), 241-254.

Lusk, J. L., and Briggeman, B. C. (2009). Food Values. American Journal of Agricultural Economics, 91, 184-196.

Maviş, F. (2005). Mönü Planlama Tekniği. Anadolu Üniversitesi Yayınları, Eskişehir No. 1614.

Odabaşı Y. ve Barış, G. (2002). Tüketici Davranısı. Kapital Medya Hizmetleri, İstanbul.

Olcay, A., ve Akçi, Y. (2014). Adıyaman Ve Gaziantep’te Yaşayan İnsanların Fast-Food İşletmelerini Tercih Nedenlerinin Faktörler İtibariyle Ortaya Konmasına Yönelik Bir Uygulama. Yönetim ve Ekonomi Araştırmaları Dergisi, 24, 158-181.

Öncü, M. A., Çatı K. ve Özbay, G. (2007). Hızlı Yiyecek İşletmelerinin Tercihinde Etkili Olan Faktörler. Dokuz Eylül Üniversitesi. Sosyal Bilimler Enstitüsü Dergisi, 9(1), 317-336.

Sürücüoğlu, M. S. ve Çakıroğlu, F. P. (2000). Ankara Üniversitesi Öğrencilerinin Hızlı Hazır Yiyecek Tercihleri Üzerine Bir Araştırma. Tarım Bilimleri Dergisi, 6 (3), 116-121.

TURAN, A. H. (2011). İnternet Alışveriși Tüketici Davranışlarını Belirleyen Etmenler: Planlı Davranıș Teorisi (TPB) İle Ampirik Bir Test. Doğuş Üniv. Dergisi, 12 (1), 128-143.

Uygur, S.M., Küçükergin, K.G. (2013) Fast Food Restoranlarda Bireyselleştirme. Müşteri Tatmini Minnettarlık ve Tekrar Satın Alma Eğilimi Arasındaki İlişki. Ege Akademik Bakış Dergisi. 13 (3), 383-392.

Ünal, S., Akkuş, G. ve Akkuş, C. (2014). Yiyecek İçecek İşletmelerinde Atmosfer, Duygu, Memnuniyet ve Davranışsal Sadakat İlişkisi. Gazi Üniversitesi Turizm Fakültesi Dergisi, 1(1), 23-49

Qin, H. and Prybutok, V.P. (2009). Determinants of customer-perceived service quality in fast-food restaurants and their relationship to customer satisfaction and behavioral intentions.The Quality Management Journal, 15 (2), 35-50.

Yağcl, M. İ. ve İlarslan, N. (2010). Reklamların ve Cinsiyet Kimliği Rolünün Tüketicilerin Satın Alma Davranışları Üzerindeki Etkisi. Doğuş Üniversitesi Dergisi, 11 (1), 138-155.

Yaman, F. (2013). Tüketici Davranışı Olarak Özgeciliğin İncelenmesi. Tüketici ve Tüketim Araştırmaları Dergisi, 5(1), 79-92.

Yıldız, Y. (2014). Tüketici Davranışları Üzerinde Sosyal Medya Etkileri: Apple ve Samsung Örneği. Kastamonu University Journal of Economics \& Administrative Sciences Faculty. 4 (2), 5-15. 